\title{
Editorial: Coexistence, Interweaving and Overlapping of Italian Migration Flows
}

Éditorial : Coexistence, imbrication et superposition des flux migratoires italiens Editorial: Coexistencia, entrelazamiento y superposición de los flujos migratorios italianos

\section{Paola Corti and Adelina Miranda}

Translator. Alexandra Pomeon

\section{OpenEdition}

\section{Journals}

Electronic version

URL: https://journals.openedition.org/remi/10428

DOI: 10.4000/remi.10428

ISSN: $1777-5418$

This article is a translation of:

Éditorial : Coexistence, imbrication et superposition des flux migratoires italiens - URL : https:// journals.openedition.org/remi/9903 [fr]

Other translation(s):

Presentazione: Coesistenza, interconnessioni e sovrapposizione dei flussi migratori italiani - URL https://journals.openedition.org/remi/9933 [it]

\section{Publisher}

Université de Poitiers

\section{Printed version}

Date of publication: 1 April 2018

ISBN: 979-10-90426-61-0

ISSN: 0765-0752

\section{Electronic reference}

Paola Corti and Adelina Miranda, "Editorial: Coexistence, Interweaving and Overlapping of Italian Migration Flows", Revue européenne des migrations internationales [Online], vol. 34 - n 1 | 2018, Online since 20 April 2019, connection on 19 April 2022. URL: http://journals.openedition.org/remi/10428; DOI: https://doi.org/10.4000/remi.10428

This text was automatically generated on 19 April 2022.

(C) Université de Poitiers 


\title{
Editorial: Coexistence, Interweaving and Overlapping of Italian Migration Flows
}

\author{
Éditorial : Coexistence, imbrication et superposition des flux migratoires italiens \\ Editorial: Coexistencia, entrelazamiento y superposición de los flujos migratorios \\ italianos
}

\section{Paola Corti and Adelina Miranda}

Translation : Alexandra Pomeon

1 At a time when Italy is increasingly in the international spotlight as a result of policies aimed at refoulement of foreign nationals at its national borders implemented by successive governments, this REMI dossier offers a critical look at the migratory history of this country. We recognise as a starting point that migration has become a highly political subject across Italy/ at the very core of Italian society. The arrival of persons who cross the Mediterranean has been accompanied by the development of various forms of rhetoric. As shown in the statements of two collective subjects operating in the Italian media-political space - Christian churches and the Northern League - the legitimacy or illegitimacy of migrants' presence now oscillates between two extremes: the universality of humanity and xenophobic and racist rejection (Miranda, 2018). In any case, the visibility of the phenomenon is based on a series of dramatic events which have brought to the centre of media and political attention certain locations, such as the island of Lampedusa, which was nominated for the Peace Prize and which has been the subject of numerous films and documentaries, such as Fuocoammare, by Gianfranco Rosi, a prize-winner in Berlin in 2016.

In this context, it is essential to adopt a detached view in order to put into perspective current analyses, which sometimes hide the complexity of the phenomenon. This position takes account of the fact that knowledge produced by the West "no longer has a monopoly on talking and writing about cultures" (Saillant, Kilani and Graezer Bideau, 2011: 13). The emergence of these new sites of knowledge challenges the historical, 
economic and cultural conditions which guide Western thought and contribute to building geopolitical knowledge which is redefining the centres and peripheries within a globalised epistemic space (Mignolo, 2001). In order to observe the migration dynamics produced "by the centre, from the centre", we draw on this position, together with the epistemological tradition of De Martino (2002). According to this Italian anthropologist, exercising "critical ethnocentrism" represents an awareness of the limits of the intellectual categories and tools used by the Western world in order to comprehend the historic opportunities of humans. Awareness of these limits leads us to experiment with new research approaches, avenues and methodologies.

3 Applied to the study of Italian migration, this perspective leads to several critical observations. Analyses of Italian migration patterns encourage researchers to develop new interpretative tools to enable examination of phenomena which are inconsistent with the construction of coherent and linear interpretative frameworks (Fabian, 2000). In this editorial we will consider two themes: the first relates to the coexistence of various forms of migration and the second underlines the issues at stake in the categorisation of migrants. They will lead us to argue that Italy, as a result of its long history of migration, is a paradigmatic case, a sort of laboratory which demonstrates the inadequacy of "conventional" migration paradigms.

\section{The various forms of migration}

4 The arrival of foreign nationals in Italy has seen a renewal of research on migration, which until then had focused on emigration. The role played by the media and the perception of immigration by the population have provoked the opening up of debates on immigration, but also on emigration, as shown by the literary success of stories, accounts and novels published on this theme (Colucci, 2007; Sanfilippo, 2015), as well as the establishment of numerous municipal, regional and national museums such as the Museo Nazionale dell'Emigrazione Italiana ${ }^{1}$. The adoption of new theoretical and methodological approaches (Gozzini, 2005; Corti and Sanfilippo, 2009; Bonifazi, 2013) has enabled studies on emigration to emerge from the academic setting to which such research has long been confined. Indeed, as a result of the repeated amnesia of the Italian political class, until then research on migration had never found its place in national history or collective memory (Martellini, 2003; Corti, 2005 and 2013; Sanfilippo, 2015). This renewed interest generated a proliferation of studies. The publication of a volume devoted entirely to migration in the Storia d'Italia contributed to the recognition that emigration is, alongside Italian Unification, one of the most significant phenomena in the country's history (Corti and Sanfilippo, 2009). These works also contributed to a better understanding of the role of Italian migration, the deep significance that it still has in the European and Mediterranean context and the fact that it has raised a series of critical questions in relation to theories based on an evolutionary vision of migration in migration studies.

5 The papers presented here follow this approach and confirm that the history of Italian migration is plural, structured around the coexistence of different forms of migration. For a very long time, Italy was considered only to be a country of emigration, which following a cycle of mass exodus had been transformed into a country of immigration. Yet, the Italian migratory framework has always been and continues to be stratified as demonstrated in Matteo Sanfilippo's article. This author reconstructs the history of 
mobility from the Unification of the country until today and, as in the works conducted at the end of the twentieth century, he shows that the intertwining of different forms of mobility - emigration and immigration, internal mobility, circulation of emigrants between different countries - is not unprecedented. Today, as in the past, Italians continue to leave for foreign countries (Tirabassi and Del Prà, 2014; Sanfilippo and Vignali, 2017) and at the same time, just like immigrants, they are caught up in intense movement inside Italy.

6 Michele Colucci and Stefano Gallo, in their article, describe the continuities between international and internal migration, revealing their variability depending on the historical period and the actors involved. The research paper by Anna Badino completes this overview, offering a comparison between mobility from southern to northern Italy and immigration of Italians to Marseille. These contributions lead to two observations. Firstly, that the reorganisation of social relations in societies of arrival follows the same rationales abroad as in northern Italy. Secondly, that these migration dynamics occupy a similar place in the migration histories of Spain, Greece and Portugal. The analyses focused on Italy confirm that migration is an inherent feature of societies around the Mediterranean and underline the need to observe the various facets of this phenomenon in order to give an account of developments and continuing features, taking into consideration the politicisation of the issue (Miranda, 2008a; Schmoll, Thiollet and Wihtol de Wenden, 2015). This is not a new development, as highlighted by the overviews provided by the contributions of Augusta Molinari, Elena Ambrosetti and Angela Paparusso. Augusta Molinari revisits the departure of ships full of Italian migrants heading for the Americas. She reminds us of the extent to which this image, a quintessential symbol of emigration, conjures up forms of violence, which in the past as in the present, are the consequence of migration policies and that sea journeys are experiences which themselves structure the future of each migrant. However, as noted by Elena Ambrosetti and Angela Paparusso, the Mediterranean crossing is increasingly linked to the distinction between asylum seekers and economic migrants and to an approach to management of migration developments which considers migration as a security problem.

7 The research presented in this dossier demonstrates the heuristic value of varying the focus of the historical perspective on migration developments, but also on the diverse spatial and political levels - local, regional, national and international - while appropriating the subjective element. As highlighted in the study by Selenia Marabello and Bruno Riccio on migrants arriving from Senegal and Ghana in the Emilia region, the analysis of the biographical experience is an essential analytical aid to understanding the ways in which economic and political processes are interlinked, as demonstrated by the theories on networks and transnationalism (Collinson, 1993; Tarrius, 1993; Miranda, 1996; Sassen, 1996; Vertovec, 2009). This approach, which draws on a combination of geographic and historical scales encourages us to rethink interpretative models, as shown by the example of Italians in France.

8 The current revival of interest in the history of this migratory pattern is related to various factors. Firstly, it is necessary to consider the growing presence of the new Italian mobility which, by the nature of its sociocultural characteristics, can be considered to be representative of the wider panorama of contemporary intraEuropean migration (Sirna, 2005; Fassio, 2014; Mourlane, 2017; Pfisch and Schmoll, 2017). Secondly, account must be taken of the dissemination of public initiatives which 
reflect the changes in perceptions of immigration from the peninsula by different generations of Italians in France (Ghidina and Violle, 2014). The recovery of collective memory by new generations materialises in the form of various local initiatives and cultural events (Teulière, 2002; Mourlane, 2017) which contribute to shifting the focus of the field of study from history to experiences (Teulières, 2011; Gastaut, 2012; Mourlane, 2015; Felici, 2017) and art (Guibal and Cogne, 2011; Mourlane and Regnard, $2013)^{2}$. Thirdly, as a result of its long duration and it impact on French economic and cultural realities, this migratory pattern may be considered as "a sort of summary of the history of immigration in France with all the uncertainties it carries: expressions of racism, religious intolerance as well as artistic, cultural and gastronomic contributions which have enriched the daily lives of the French" (Stora, 2017: 9).

9 Research therefore confirms that the journeys of Italian migrants in France have been and continue to be of a less linear nature than that suggested by the model advocated by assimilationist orthodoxy. As a result, the analysis of this example is heuristic, in order to discover other migratory experiences and to encourage research with a comparative perspective. In addition, this example leads to two questions. Given that at the subjective level researchers have managed to study emigration and immigration as generated concomitantly (Sayad, 1991), why do they continue to analyse the various forms of migration separately? Does the lack of attention to the forms of co-existence, overlapping and intertwining of the various forms of migration (whether stemming from slavery, colonialism, urbanisation or industrialisation) contribute to a sort of hierarchy of forms of migration and naturalisation of differences?

\section{The issues at stake in the categorisation of migrants}

10 By challenging the caesura between Italian emigration and immigration we call into question the categories used to study the two phenomena. The adoption of a comparative historical approach reveals the variability of these categories as well as the continuous and discontinuous aspects which define their limits. A reminder sheds light on this difficulty: in Italy, the word "emigrant" has been used to define both internal and international migrants. During the first major survey undertaken in the 1960s in the peripheral districts of Milan and Turin, Alasia and Montaldi (1960) described the living conditions of emigrants living in the "Coreas" (Koreas) ${ }^{3}$. These authors gave an account which might seem surprising today: among these Italians there were numerous "illegals", who worked in particular in the construction industry where they were exploited by local entrepreneurs. The image is the same as that portrayed in the numerous studies on Italians who crossed national borders. For their part, Italians residing abroad have fought to have the COEMIT (Comitato dell'Emigrazione Italiana established in 1985) renamed as the COMITES (Comitato degli Italiani all'Estero), asserting their desire to distance themselves from the figure of emigrant.

11 More generally, the Italian example highlights the fact that today the concepts of migrant and migration have undergone a kind of trivialisation which seems to invalidate their scientific value, particularly since they have been absorbed by the political sphere. Italians, who realised the significance of immigration at a late stage, reacted with denial or overdramatization and above all by severing the link between immigration and emigration. This process is especially interesting since it highlights the way in which migration is used in the development of processes of identity and 
"otherness". Indeed, scientific analyses show that the figures of immigrant and emigrant are intertwined, but this entanglement should not hide the fact that in its common meaning the figure of immigrant is not the mirror image of that of emigrant. Considering oneself as belonging to a country of emigration is not the same as considering oneself as belonging to a country of immigration; the ranges of values, representations, judgements which correspond to the two categories do not coincide.

The introduction of the perspective of social relationships into studies on migration confirms that the figures of emigrants and immigrants embody the processes of subordination and domination in different ways. Fabienne Le Houérou's reexamination from a gender perspective of the case of the "insabbiati" shows how the sexual misconduct committed by Italians was based on a fascist ideology which, praising the superiority of the white man, encouraged the domination fantasies of the colonists. Adelina Miranda's article reveals unexpected features of continuity: the semantic frontiers between Italians and immigrants increasingly evoke an intertwining of gender/race based on the image of a migrant who is male/black/out of work.

The contributions presented here show that in order to understand the variability of migration patterns and the hierarchical relationships between the various migrant figures, it is necessary to contextualise population movements in space and time. Furthermore, they call into question our epistemological practices: can we continue to resort to a single term to study situations which reveal themselves to be increasingly dissimilar? An overview of the papers presented in this issue draws attention to the fact that concepts of migrants and migration appear to be less and less efficient in theoretical and methodological terms. The contributions lead to the observation that sub-categories of the concept of migrants have established themselves in scientific discourse: "new" and "old" migrants; "illegal", "irregular" and "undocumented" migrants; skilled expatriate migrants; political refugees, asylum seekers; established workers and seasonal workers, etc. The multiple typologies refer to statistical categories which organise migrants based on their motives and their modes of departure and arrival, but also to legal, political and standard frameworks. Their use reminds us that the boundaries between these categories are reversible and unstable, that causes and motives overlap during migrants' journeys, at times consistent, and at others conflicting with migration policies.

The studies of the Italian example discussed in this dossier suggest that, in the context of migration studies, on the one hand, it is necessary to move beyond a distinction between migrants and non-migrants and, on the other, it is impossible to define the spheres of migration, within which old and new protagonists move, through the simple analysis of territorial trajectories. Likewise, it is no longer conceivable to employ categories which reflect, from a semantic point of view, the typologies used in a political discourse which instrumentalises them. 


\section{BIBLIOGRAPHY}

Alasia Franco e Montaldi Danilo (1960) Milano Corea. Inchiesta sugli immigrati, Milano, Feltrinelli, $328 \mathrm{p}$.

Bonifazi Corrado (2013) L'Italia delle migrazioni, Bologna, il Mulino, 299 p.

Collinson Sarah (1993) Europe and International Migration, London, Pinter, 189 p.

Colucci Michele (2007) Storia o memoria? L'emigrazione italiana tra ricerca storica, uso pubblico e valorizzazione culturale, Studi Emigrazione, 167, pp. 721-728.

Colucci Michele e Gallo Stefano (Eds.) (2017) In cattedra con la valigia, Gli insegnanti tra stabilizzazionee mobilità, Rapporto 2017 sulle migrazioni interne in Italia, Roma, Donzelli editore, 188 p. Colucci Michele e Gallo Stefano (Eds.) (2016) Fare spazio. Rapporto 2016 sulle migrazioni interne in Italia, Roma, Donzelli editore, $170 \mathrm{p}$.

Colucci Michele e Gallo Stefano (Eds.) (2015) Tempo di cambiare. Rapporto 2015 sulle migrazioni interne in Italia, Roma, Donzelli editore, $172 \mathrm{p}$.

Colucci Michele e Gallo Stefano (Eds.) (2014) L'arte di spostarsi. Rapporto sulle migrazioni interne in Italia, Roma, Donzelli editore, $170 \mathrm{p}$.

Corti Paola (2013) Temi e problemi di storia delle migrazioni, Viterbo, Sette Città, 132 p.

Corti Paola (2005) L'emigrazione italiana e la sua storiografia: quali prospettive?, Passato $e$ presente, 64, pp. 89-95.

Corti Paola e Sanfilippo Matteo (2012) L'Italia e le migrazioni, Bari-Roma, Laterza, 183 p.

Corti Paola e Sanfilippo Matteo (Eds.) (2009) Storia d'Italia. Annali 24. Migrazioni, Torino, Einaudi, $804 \mathrm{p}$.

De Martino Ernesto (2002) La fine del mondo, Torino, Einaudi, 727 p.

Fabian Johannes (2000 [1983]) Il tempo e gli altri, La politica del tempo in antropologia, Napoli, L'Ancora del Mediterraneo, $233 \mathrm{p}$.

Fassio Giulia (2014) L'Italia non basterebbe. Migrazioni e presenza italiana a Grenoble dal secondo dopoguerra, Roma, Cisu, $302 \mathrm{p}$.

Felici Isabelle (2017) Sur Brassens et les autres « enfants » d'Italiens, Montpellier, Presses Universitaires de la Méditerranée, 259 p.

Gastaut Yvan (Éds.) (2012) Terres et gens de frontières : le cas exemplaire des migrations dans l'espace frontalier des Alpes du Sud, XIXe et XXe siècle, Migrations Societé, 140, pp. 51-298.

Ghidina Jean-Igor et Violle Nicolas (Éds.) (2014) Récits de migration. En quête de nouveaux regards, Clermond-Ferrand, CELIS, $334 \mathrm{p}$.

Gozzini Giovanni (2005) Le migrazioni di ieri edi oggi, Una storia comparata, Milano, Bruno Mondadori, $195 \mathrm{p}$.

Guibal Jean et Cogne Olivier (Éds.) (2011) Un air d'Italie. La présence italienne en Isère, Isère, Éditions du Musée dauphinois, 208 p.

Martellini Amoreno (Ed.) (2003) Cinque domande sulla storiografia dell'emigrazione a Emilio Franzina e Ercole Sori, Storia e problemi contemporanei, 34, pp. 15-31. 
Meridiana (2018) Immigrazione, 91, $269 \mathrm{p}$.

Mignolo Walter (2001) Géopolitique de la connaissance, colonialité du pouvoir et différence coloniale, Multitudes, 6 (3), pp. 56-71.

Miranda Adelina (2018) Contrastes d'images. Les usages culturels de la figure des migrants arrivant en Italie par la Méditerranée, Revue Science and Video, 7, [en ligne]. URL : http:// scienceandvideo.mmsh.univ-aix.fr/numeros/7/Pages/02.aspx

Miranda Adelina (2008a) Introduzione, Studi Emigrazione, 172, pp. 771-786.

Miranda Adelina (2008b) Migrare al femminile. Dinamiche culturali e appartenenza di genere in situazioni migratorie, Milano, McGraw-Hill, 198 p.

Miranda Adelina (2007) Le donne italiane in emigrazione tra passato e presente, in Fondazione Migrantes, Rapporto Italiani nel mondo 2007, Roma, Edizioni Idos, pp. 133-144.

Miranda Adelina (1996) Migrants et non-migrants d'une communauté italienne, Paris, L'Harmattan, $187 \mathrm{p}$.

Mourlane Stéphane (2017) Retour de mémoire, in Stéphane Mourlane et Dominique Païni Éds., Ciao Italia. Un siècle d'immigration et de cultures italiennes en France, Paris, La Martinière, pp. 176-183.

Mourlane Stéphane (Éd.) (2015) Les Italiens dans le Sud-Est de la France : nouvelles perspectives, Archivio storico dell'emigrazione italiana, 11, pp. 7-93.

Mourlane Stéphane et Païni Dominique (Éds.) (2017) Ciao Italia. Un siècle d'immigration et de cultures italiennes en France, Paris, La Martinière, 192 p.

Mourlane Stéphane et Regnard Céline (Éds.) (2013) Empreintes italiennes. Marseille et sa région, Lyon, Lieux Dits Éditions, 132 p.

Nicosia Alessandro e Prencipe Lorenzo (Eds.) (2009) Museo Nazionale dell'Emigrazione Italiana, Roma, Gangemi editore, $494 \mathrm{p}$.

Pfirsch Thomas et Schmoll Camille (2017) Une nouvelle vague d'immigration italienne en France, in Stéphane Mourlane et Dominique Païni Éds., Ciao Italia. Un siècle d'immigration et de cultures italiennes en France, Paris, La Martinière, pp. 179-181.

Saillant Francine, Kilani Mondher et Graezer Bideau Florence (Éds.) (2001) Manifeste de Lausanne. Pour une anthropologie non hégémonique, Montréal, Liber, 143 p.

Sanfilippo Matteo (2015) Nuovi problemi di storia delle migrazioni italiane, Viterbo, Edizioni Sette città. 206 p.

Sanfilippo Matteo e Vignali Luigi Maria (Éds.) (2017) La nuova emigrazione italiana, Studi Emigrazione, 207, pp. 355-510.

Sassen Sakia (1996) Migranten, Siedler, Flüchtlinge, von der Massenauswanderung zur Festung Europa, Frankfurt, Fischer Tascenbuch, 215 p.

Sayad Abdelmalek (1991) L'immigration ou les paradoxes de l'altérité, Bruxelles, De Boeck, 331 p.

Schmoll Camille, Thiollet Hélène et Wihtol de Wenden Catherine (2015) Migrations en Méditerranée. Permanences et mutations à l'heure des révolutions et des crises, Paris, CNRS Éditions, $282 \mathrm{p}$.

Sirna Francesca (2005) Italiani in Francia: un'integrazione riuscita?, Studi Emigrazione, 160, pp. 786-805. 
Stora Benjamin (2017) L'immigration italienne en France, in Stéphane Mourlane et Dominique Païni Éds., Ciao Italia. Un siècle d'immigration et de cultures italiennes en France, Paris, La Martinière, pp. 8-11.

Tarrius Alain (1993) Territoires circulatoires et espaces urbains : différentiation des groupes migrants, Les Annales de la recherche urbaine, 59-60, pp. 51-60.

Teulières Laure (Éd.) (2011) Italiens. 150 ans d'émigration italienne en France et ailleurs, Toulouse, Éditalie éditions, $500 \mathrm{p}$.

Teulières Laure (2002) Mémoires et représentations du temps de guerre, Studi Emigrazione, 146, pp. 400-414.

Tirabassi Maddalena (2009) I luoghi della memoria delle migrazioni, in Paola Corti e Matteo Sanfilippo Eds., Migrazioni, Storia d'Italia, Annale 24, Torino, Einaudi, pp. 709-724.

Tirabassi Maddalena e Del Prà Alvise (2014) La meglio Italia. Le mobilità italiane nel XXI secolo, Torino, Accademia University Press, 240 p.

Vertovec Steven (2009) Transnationalism, London, Routledge, 205 p.

\section{NOTES}

1. This museum is currently closed pending a new collocation. It is located in the Vittoriano (monument dedicated to Victor Emmanuel, the first King of Italy, in Rome), which has become the national symbol of this aspect of history (Lombardi and Prencipe, 2009; Tirabassi, 2009).

2. For example in 2017, the exhibition Ciao Italia!, at the Musée de l'Immigration in Paris (Mourlane and Païni, 2017), was shown alongside the related conference, L'Italie pour bagage (June 2017).

3. The "Coreas" were the shantytowns where Italian emigrants lived; these places resembled images of the towns destroyed during the Korean War.

4. The majority of these internal emigrants were "illegals" since the fascist law which prohibited any person without regular, declared work to change their place of residence, was still in force. As a result, internal Italian emigrants could not have a residence without regular work, but they could not have regular work without first having a residence.

\section{INDEX}

\section{Geographical index: Italie}

Mots-clés: émigration, immigration, politiques migratoires, catégorisation des migrations, déconstruction des paradigmes migratoires

Palabras claves: Italia, emigración, inmigración, políticas migratorias, categorización de las migraciones, deconstrucción de los paradigmas migratorios

Keywords: Italy, emigration, immigration, migration policies, categorization of migrations, deconstruction of migratory paradigms 


\section{AUTHORS}

\section{PAOLA CORTI}

Historian, Professor, University of Turin, Department of Philosophy and Educational Sciences, Via S. Ottavio 20, 10124 Turin, Italy; paola.corti@unito.it

\section{ADELINA MIRANDA}

Anthropologist, Professor, MIGRINTER, University of Poitiers/CNRS, MSHS, Bât. A5, 5 rue

Théodore Lefebvre, TSA 21103, 86073 Poitiers cedex 9; adelina.miranda@univ-poitiers.fr 